\title{
National Textbook Narratives and Historiography: Presenting a Same That is Never the Same
}

\author{
Nicole Gotling \\ University of Vienna
}

\section{Abstract}

National textbook narratives are written from particular national perspectives and goals. Thus, "the same is never (or at least not always) the same" and what we learn depends on the context of when and where we are learning it. When it comes to major conflicts between nations or states, how one handles the telling of the same conflict event can be especially poignant. Starting from the writing of national events, this text looks back to another large-scale (inter-)national conflict, the Prussian Wars (1864-1871), to discuss how the four different developing nationstates of Germany (via Prussia), Denmark, Austria, and France elaborated unique historical narrative trajectories (from the 1860s to 1910s) for their own national curricula and future citizens. From the findings, which discuss the ways these developing nation-states represented their national ideals, identity, and goals in their national Prussian War narratives in textbooks, we then come back to the present with a better understanding of how to approach current international events and nation-building processes.

Keywords: historiography; national identity; national narratives; nation-building; Prussian Wars; textbooks.

\section{Introduction}

National historiographies and narratives are written and purposed with particular national perspectives and goals (see Berger, 2007; Kohn, 1946/1944, p. 23; Osterwalder, 2011). Especially from the nineteenth century onward, historians have been revamping their approach to national history writing and seeing "themselves as pedagogues of the nation," (Berger, 2007, p. 38) who have striven "to emphasise the unity of the nation and, frequently, the superiority of their nation over other nations" (Berger, 2007, p. 39). 
Thus, especially when it comes to national "truths" and histories, "the same is never (or at least not always) the same" and what we learn depends on the context of when and where we are learning it. In addition, the (created) citizens of the state who attended or are attending the national (public) school system are normally not made aware of becoming fluent in a non-universal, national understanding of history; nor are they trained in discerning the distinct national aspect(s) of the development and teaching of those national literacies (Tröhler, 2020).

This differentiation in the way national and international events are understood to have played out along a global historical timeline can lead to misunderstandings and conflicts. Thus, when it actually comes to major conflicts between (or within) states, how one handles the telling of the same conflict event can be especially poignant. We usually only have to look across ideological and political borders in order to see that what is considered the "same conflict" is not handled or retold in the same way between different national discourses or state entities, nor even, often, over time. Indeed, that is the point here: despite world culture theories' suggestions of isomorphism and standardization around the globe, multi-case comparisons show that what seems to be the same is actually not (Boli \& Thomas, 1997; Meyer et al., 1997), and national narratives in curricula do produce distinctions in perceptions and cultural constructions of the world in the creating of future citizens.

Different historiographies are linked to state nation-building and sustaining efforts, especially through their role in state educational institutions. In an understanding that the nation-building processes of states follow the long-held international pattern of educationalizing the problem of uniting their populations as a cohesive, national "us" and creating their ideal future national citizens via national curricula (Tröhler, 2016b, p. 282), which themselves typically include national subjects such as history and geography (Dahn \& Boser, 2015), states are tasked with writing about conflicts and events for their own constituents. Narratives are produced for national textbooks from a national perspective so that future national citizens learn specific ideals and "truths." Then, as these ideals change over time, so too do the national narratives, which are redeveloped so that the national "truths" continue to match accordingly.

In this way of nation-building that is supported by national narratives in nationallyfocused subjects and curricula, educationalizing the creating of future (ideal, national) citizens stays at the core of the educational systems (Cummings, 1999, p. 425; Tröhler et al., 2011). As a result of nation-states (or more generally, those nations and states in the processes of developing as nation-states) enforcing that their future national citizens attend mass public school systems (Tröhler, 2016a, p. 10), the engineered national curricula (and then hence the national ideologies, goals, "us" and "other" embedded within the curricula) have been able to be implemented into the everyday lives of these future citizens and thus normalized. In this way, too, not only is the "nation" normalized, but the future national citizen also comes to identify as a member of the collective, national "us." Through such means as teacher training, textbooks, and 
teaching materials alongside the curricula, the "nation" is imbued into the commonplace in such a way that it is natural and often even unnoticeable (see, to name a few, Billig, 1995; Calhoun, 2007; Özkırıml1, 2017). It is these particular types of educationalizing tools, the national textbooks and teaching materials such as maps, that have been analyzed for our case here.

\section{An exemplary case: The Prussian Wars (1864, 1866, 1870-71)}

The extent to which the nation, along with its conjoined concept of national identity, has been incorporated into history and geography textbooks is shown here in a comparative case study of how different nations, states, nation-states (or any variation therein) treated the "same" set of historical events. The ensuing different understandings of what would be called this "same" set of events can be evidenced through analyses of the national historiographies and narratives of previous multinational conflicts. For example, if we look back to Europe's long nineteenth century, one of the major events (or conflicts) in nation-state-building which stands out is the unification of Germany. In the process of uniting the many different German states as a nation-state, the powerful state of Prussia led three successful wars against their neighbors: the Second Schleswig War of 1864, the Austro-Prussian War of 1866, and the Franco-Prussian War of 1870-71. This set of wars, often called the Prussian Wars, changed the face and direction of Europe within less than a decade.

The Prussian Wars not only saw the creation of the German nation-state as the German Empire from conflicts against such developing nation-states ${ }^{1}$ as Denmark, Austria, and France, but in many cases, it also helped (re-)instigate the push for mass, compulsory schooling (Tröhler, 2016b) with national curricula which were geared towards teaching and reminding students (future national citizens) which nation they belonged to and loved, and what it meant to be part of that nation ("us"). Therefore, Prussia, ${ }^{2}$ Denmark, Austria, and France each developed their own historiographies and narratives for textbooks and other teaching materials (such as maps) which explained the Prussian Wars in nation-appropriate ways; and each developed these historiographies and narratives in ways which remained relevant to the developing nation-state's trajectory.

\footnotetext{
${ }^{1}$ As each of the four regions involved in this study: Germany (as Prussia), Denmark, Austria, and France, followed unique paths towards nation-statehood, they are generally referred to, here, as "developing nationstates." This should portray that, even though they were at very different stages and directions of development during the decades studied here (1860s-1910s), each, at one point or another, did develop into a nation-state (although, for Austria, this status was not fully achieved and maintained until after the Second World War). ${ }^{2}$ Although this study is discussing nation-state-building and the creating of national citizens through the case of Germany and the Prussian War conflicts, it is actually the Prussian historiographies and narratives that are discussed in the study. There were many different, sovereign German states up through the 1860s, but it was Prussia who united the German states as the German Empire through the Prussian Wars, and it would have been the Prussian narratives which became the hegemonic German narrative.
} 
The following analyses of history and geography textbooks, which were published between the 1860s and 1910s, were conducted within a comparative and historical discourse analysis approach (Foucault, 1980; Landwehr, 2018; Rüsen, 1996) according to the framing of the textbooks and their content, their use of different narrative (modifying and recontextualizing) strategies, and the use or nonuse of actors and emotions (Fairclough, 2003, pp. 23-28; Montesano Montessori, 2014; Rogers, 2011). Additionally, the future national citizens were represented with their nation-state's image of the national "us" as opposed to who the "others" were outside their borders (see Friederich, 2014; Samuelsson \& Wendell, 2016). The way that the Prussian Wars were framed and written about show that the four different developing nation-states of Germany, Denmark, Austria, and France developed unique historical narrative trajectories for their own national curricula and future citizens. What follows are the findings of this exploration into how the "same" major international conflict of the Prussian Wars was made nationally distinct in Prussian, Danish, Austrian, and French narratives and the ways these narratives exemplified the varying national goals, especially in relation to the idea of a national identity for future citizens to embody.

\section{Prussia's German Empire and the victor's narrative}

In general terms, since the German state of Prussia was the leader and grand victor in each of the three Prussian Wars - our understanding of the Prussian Wars, as they are often called, supports the idea that "history" as we know it has been "written by the victors." So here, before discussing the Prussian narratives, is a "general" history of the Prussian Wars which provides some context for the national narratives that follow. The Second Schleswig War (February 1 until October 30,1864) was a continuation of the First Schleswig War (starting in 1848 until, according to the Prussian narrative, 1851). The Schleswig Wars revolved around an ancient decree from 1460, which stipulated that the territories of Schleswig and Holstein should never be separated, in addition to complications with royal lines of succession concerning the territories of Schleswig, Holstein, and Lauenburg. Even though Austria had been (however unwilling) an ally of Prussia's in the Second Schleswig War, two years later, Prussia and its other allies attacked Austria in the Austro-Prussian War (June 14 until July 22, 1866) - from which victory Prussia became the greatest German state and was able to unite most of the other German states into a confederation without Austria. A few years of politics played out in the subsequent years between the Prussian King Wilhelm I, Chancellor Bismarck, and France, until, through a series of events, France took up an offensive against the Prussian-led German Confederation. This event became known as the Franco-Prussian War (July 19, 1870 until January 28, 1871) and with an outcome of the French Alsace and Lorraine regions being annexed to Germany and culminating the series of wars with a united German Empire (1871). The Prussian national narratives that resulted from these wars were ones of "peace" for the German Empire which tried to uphold ties to its Germanic (i.e. Austrian) neighbors, while at the same time 
instilling an antagonistic defensive position against its other combative neighbors, such as Denmark and France.

Throughout the post-Schleswig Wars narratives, Prussia maintained their role in the wars as honorable. By referring to the actions of the Danish in specific ways, such as severe, disregardful, and "harsh" (Hopstein, 1871, p. 32), the Prussian narratives paint the picture of a heavily Germanized Schleswig, Holstein, and Lauenburg as being victims to a deviant nation. To add to this image from a nationally-rooted standpoint, Prussian narratives declared that, not only were Schleswig, Holstein, and Lauenburg actually German states, but the King of Denmark (who was also the Duke of SchleswigHolstein and Lauenburg) had "exterminated the German language" in Schleswig and had "lead the Danish language into churches and schools," (Jaenicke \& Stohrer, 1891, p. 2) thereby implying the use of Danish in their everyday lives. With the justification for Prussia's (and Austria's) infiltration of Denmark marking the Second Schleswig War of 1864 laid out thus, in terms of historical agreements and national language, the future Prussian (and German Empire) citizens were to learn that Germans were acting nobly on behalf of historical duty and fellow German nationals.

Prussia's grand narrative concerning the Austro-Prussian War of 1866 also factored in the national German element as highly relevant to this portion of the historiography even referring to this short, seven week-long war as the German War. Despite the shared German element and Austria's previous support of Prussia in the Second Schleswig War, Austria was still attacked by Prussia and left out of the united Germany (until 1938). This can largely be seen as due to a contest of powers, which Prussian narratives described as a jealous rivalry: Austria had long been one of, if not the, most powerful leading German states since the fourteenth century; and Prussia had been, especially over the course of the eighteenth and nineteenth centuries, an up-and-coming power who would contend with Austria on many political and religious matters (Protestant versus Catholic; for a discussion on church and state relations within national education systems, see Mette Buchardt's article in this issue). Therefore, when Prussian narratives focused on their "regret" at having to go to war with their German brethren, it was not real regret or remorse that was meant, but a post-war plan to instill their future citizens with a respect for Germans. In line with this respect for Germans of the nonPrussian states, Prussian historiography also maintained the unifying "us" narrative that those fighting for the other German states were strong, successful armies headed by very important German leaders.

One of the central themes to the Prussian historiographical narratives was that Prussia and the Prussian King, Wilhelm I, had worked so hard and deservingly for a lasting peace in Germany. This theme was most evident surrounding their narratives on the Franco-Prussian War of 1870-71, stating that France and the French leader, Napoleon III, would not allow Germans to stay peaceful. The manipulative French were "full of envy and jealousy over Prussia's happy successes," and so Napoleon III wanted to destroy this felicitous German mood (Hopstein, 1871, p. 34; Roßbach, 1911, 
p. 34). By depicting the French in a very negative light and antagonistic, not only to Germany and their eminent, beloved leader, but also to German "peace," PrussianGerman narratives used the important historiographic nation-building tool of creating an "us" versus a "them." To be realistic about it, Prussia and the other German states held a strong grudge against France following the long Napoleonic Wars (1803-1815), and they handily continued to play upon this animosity in the Franco-Prussian War narratives so that the future Prussian-German citizens would be instilled with a strong sense of what it meant to be a hardworking and peace-loving German as opposed to their hateful French neighbors. This strong "us" versus "them" narrative no doubt helped support the alliances and actions of the subsequent World Wars.

At the same time that the Prussian narratives described their counterparts in each of the three Prussian Wars, they also included specific descriptions of estimable Prussians, to whom the future Prussian-German citizens should look as national role models. First and foremost was that the powerful (Prussian) German Fatherland strove for "peace" and being peaceful. It was even written as "fact" that the "German Empire protects the peace" (Meyer, 1892, p. 77), especially thanks to the first German king-turnedemperor, Wilhelm I. Emperor Wilhelm I was by far the preferred role model for the German Empire, and the characteristics attributed to him in the Prussian-German history books were to represent the values of the future Prussian-German citizens. These values included being hard-working, perfectionist, and yet still having an easy nature. At the same time, and in connection to the male citizen's role model, females were to look up to Wilhelm I's wife who was highly-educated.

Ultimately, one of the major themes that can be deduced from the Prussian-German narratives following the Prussian Wars and about the Prussian Wars is that the national German element was highly important. It was important in the bringing together of many different (historically) Germanic territories into one united German nationstate, one which valued national language and culture highly (Berger, 1997, p. 24) as evidenced in the chosen discourse used to describe each of the wars. When the narratives described Germans themselves, certain attributes were highlighted for the future citizens to learn to value: a disciplined work ethic, being calm and peaceful, yet strong and dutiful when and where a need of the nation demanded it (such as implied in the reasonings behind each of the wars). The Prussian narratives were thus published with the intention that the future German citizens would incapsulate this esteemed version of the Prussian "us" while learning who their friendly and hostile "other" neighbors were.

\section{Denmark's brave conflict with history}

Since there is a long history of Danish events behind the foundation of Denmark's national narratives (as they pertain to the case of the Prussian Wars), it is useful to understand their "general history" before expounding on their national textbook narratives. The case of the Schleswig Wars of 1848 and 1864, in particular, rested heavily 
on the legislative and demographic nuances of the historically Danish Schleswig and historically German Holstein territories that complicated nineteenth-century Danish and German nation-building efforts. The history of these events also tends to form the foundation of Denmark's national narrative (as it pertains to the case of the Prussian Wars), reaching far back in time to the Medieval Age when the territory of Schleswig went from being regular Danish crownlands to becoming an autonomous Danish duchy instead. Holstein, on the other hand, lay to the south of Schleswig and had been a territory of the Holy Roman Empire (of the German Nation) until 1460, when, due to intricacies between legislation and the end of the Holstein count's (who was, by that time, jointly the Schleswig duke) line of succession, the territory of Holstein also became a Danish county. Through the 1460 Treaty of Ribe, both Schleswig and Holstein were guaranteed to stay "forever united" and to maintain an autonomous capacity under the ruling of the same Duke, who by that time also happened to be the King of Denmark, Christian I. During the following centuries, Germanic Holstein was a member of the Holy Roman Empire and subsequent German Confederation and the cities and southern half of Schleswig became increasingly Germanized, with a majority of southern Schleswig's inhabitants speaking German by the time of the Schleswig Wars. Again, due to legislative wording (especially that of the Treaty of Ribe back in 1460) and to failed lines of succession, as well as to the increasing Germanization of the historically Danish southern Schleswig, the rise of nationalism in the long nineteenth century became tied to what would be called the Schleswig Question. The whole question over who should have the right to rule over Schleswig (and therefore also Holstein) was obviously complicated.

In addition to this, and relevant to some of the history behind the Prussian Wars, Denmark became, by indirect ways, an ally of the French (and therefore technically at odds with the German confederated states) during the Napoleonic Wars (180315). A few decades later, the Revolutions of 1848 would result both in instigating the First Schleswig War in 1848 and in Denmark's becoming a constitutional monarchy (1849). In 1852, a London Protocol would keep an insecure stalemate between Prussia, Denmark, and the Duchies of Schleswig, Holstein, and Lauenburg. The thin peace was kept until the Danish Royal House of Oldenburg went extinct in 1863 and the new King Christian IX passed a new constitution which tried to reestablish Schleswig as a part of the Kingdom of Denmark, thus leading to the Second Schleswig War in 1864.

With this complicated history laid out, it should come as no surprise that, opposed to the Prussian narratives, and to an extent also the Austrian, Denmark was not inclined to view Prussian and the duchies' hostilities in its territories as necessarily justifiable indeed, Denmark called Prussia's and Austria's actions unjust. The Danish narratives were ones of victimization, but not just of being made a victim by their aggressors, they had also thought that the great international powers, such as England, would come to their aid instead of just sending empty words of warning. With the Danish narratives laying out an image of a country on its own, the Danish could not be at 
fault for their actions: for having the mettle to stand their ground for the national ground against great odds, until, ultimately, needing to desert their important posts at the ancient and nationally iconic Dannevirke border fortifications in order to avoid complete destruction. How could anyone be bitter with their compatriots when they had stood alone for the Fatherland, fighting so bravely and for so long?

The Danish narratives described not just Denmark as the victim, but the Germans (Tydske; as the general enemy), the Prussians, and, when included, Austrians as the manipulative aggressors. A wealth of discursive narrative language represented to Denmark's future citizens what the characters of the ultimate, hateful "other" were: they were arrogant and cunning, playing with Denmark as if the conflict was a "game" (Allen, 1864, p. 217) in which Schleswig was the "prey" and there were no possible outs for the Danish through diplomacy; they were relentless and interfering; and acted as "tyrants" and extortionists, pillaging and plundering the Danish Fatherland, cultural heritage and economy. After winning the war, Prussia and Austria shared the three duchies between themselves until, by 1866, they got tired of these "robbed goods" and a war broke out between them. From then on, Prussia ended up with all the territories, and kept them even though the Danes in North Schleswig wanted to return to Denmark (Bang \& Ellinger, 1892, p. 98; Ramsing, 1906, p. 210).

Not all was lost and lonely for Denmark, though. Attacked by the south and let down by the east (Russia) and west (England), Danish historiography turned its attention to the north once again. Denmark and Sweden had had contentious or strained relations for centuries, but this was the time to highlight a renewed, budding relationship with one of their closest neighbors; and as the decades rolled on, Danish narratives told the future Danish citizens of the happy (royal and national) unions within Scandinavia and of "the beautiful" period of art and poetry, especially those focused on history, which had developed amongst the Nordic nations (e.g. Ramsing, 1906, pp. 212-214).

Through the trying times of the Schleswig Wars, what it meant to be Danish was also represented. The Danish narratives upheld their citizens (Borgere) as brave and willing to fight, even all by themselves and for long stretches of time, and especially if the independence and existence of the grateful Kingdom of Denmark, the Fatherland, was at stake. To act against these Danish traits would be a betrayal that would cause its people sorrow, bitterness, and anger. Also in connection to these difficult times, Danish citizens were painted in a hardy and resourceful light. By the 1870s, Danish national narratives were highlighting a focus on ecclesiastical affairs and taking care of the poor, a desire for enlightenment through Danish schools (which was considered achieved by the 1890s narratives), and that people should join rifle shooting associations as a way to awaken a spirit of love and consciousness for the Fatherland and for the home. Lastly, the Danish were expected to revere the King of Denmark and his honorable family for being free and for keeping the Danish people free (Johannsen, 1870, p. 175).

In the end, the Schleswig Wars erupted, not only due to a long and complicated history in the northern European Danish and German regions, but out of the fervent 
push for national unity and nation-building that took place in central and northern Europe, amongst other regions. The Schleswig Wars were based on regional loyalties, national loyalties, and history. Through its narrative choices, Denmark created a mean, manipulative, or reticent "other" in most of its neighbors, while establishing values of bravery and cultural heritage for the future Danish citizen, the "us" who should be happy at home and in Scandinavia. A penchant for valuing religion, nature, and the Fatherland and King followed throughout Danish historiography.

\section{Austria's narrative trajectory in search of an identity}

Austria has had a long history as an important German power, especially (politicallyspeaking) dating back to the Medieval Age with the formation of the Holy Roman Empire (of the German Nation) and the eventual and perpetual leadership of this empire by the royal Austrian House of Habsburg, later Habsburg-Lorraine, (14521806). International and national conflicts (such as the Napoleonic Wars (1803-1815) and the national Revolutions of 1848, respectively) harangued the powerful Austrian imperial state until at last, after its victor's role alongside Prussia in the Second Schleswig War of 1864 and its later defeat at the hands of Prussia in the Austro-Prussian War of 1866 , the Austrian state saw itself separated from its fellow German state counterparts halfway through that same year. In the years directly following their resounding defeat by Prussia in 1866, Austria secured new political ties to re-bolster and protect their central position in Europe (tying themselves officially to the Hungarian multinational state) thereby becoming the Austria-Hungary Dual-Monarchy in 1867.

During the decades following the Austro-Prussian War and the strategic union with Hungary, Austrian historiography would, to different extents, harken back to a national German heritage while also promoting a present discourse that could distinguish an Austrian identity from the German dust. This Austrian narrative trajectory turned out to develop, in a way, a circuitous, circinate path. While it took several decades for the German nation of Austria to branch out and develop its identity as separate from that of their ancient Germanic ties, by the Interwar period, and especially during the 1930s, the Austrian narrative was returning to their "brothers" in a more German (not to be confused with Deutschland) narrative before eventually being annexed by (and reunifying with) the German Reich in March of 1938 (see also, Koláŕ, 2010, p. 326).

As mentioned, Austria had supported Prussia's initiative to fight Denmark for the Duchies of Schleswig, Holstein, and Lauenburg. Yet, even though Austria had played this supportive role in Prussia's Second Schleswig War against Denmark in 1864, Austrian narratives hardly ever focused on the events or characteristics of this war itself. Instead, if it was included in the narratives at all, the Second Schleswig War was commonly written about as the preliminary event that led to the Austro-Prussian War of 1866. By the late nineteenth century, Austria was developing more historiographic independence and focused more attention on its personal war with Prussia, painting Prussia in more of a war-mongering light and thereby no longer needing to explain so 
much about what had led up to their own Austro-Prussian German War of 1866 (or, in other words, the causal events of the Second Schleswig War of 1864). Their narratives thus spent less type on the conflicts with Denmark, until, by textbooks published in 1910 (Würfl, 1910, p. 117), the war of 1864 was no longer even mentioned.

From the 1860s into the 1880s at least, the Austro-Prussian War was historiographically framed as yet another lead up: this time to the "Fall of France's Napoleon III." Yet this changed with time, and eventually by the late 1880s (as Austrian historiography started to produce a narrative that focused on Austria and the development of a more distinct Austrian identity) Austria took charge of its narrative concerning the Austro-Prussian War. Along these Austrian narratives (and similarly to the Prussian narratives), the Austro-Prussian War was the Deutscher Krieg - German War - of 1866; and it especially concerned itself, at least for the most part, with the roles and alliances of Germans within it. In the 1860s and 1870s, Austria had been, in few words, a victim of Prussia who had needed to cry out to its neighbors for help; whereas by the 1910s, Austria clearly stated that the other states of the German Confederation (of which there were many in the Deutscher Bund) had supported them in the war (and Prussia only had the non-German Kingdom of Italy as an ally). In connection to the lack of German allies for Prussia, narratives from the 1890s onwards also depicted Prussia in a meaner light: headed by a greedy and overinfluential Bismarck (as opposed to Prussia's positive model of Wilhelm I), they were aggressors who sought supremacy in the region and seized an unwarranted opportunity of attacking Austria in order to gain it (e.g. Rusch et al., 1909, p. 62). In this depiction of the Prussian neighbor as a mean and aggressive enemy, the ancient German national element was not at risk and a seed of an Austrian "us" versus a Prussian "other" could start to grow for their future citizens.

A depiction of the Prussian "other" alone could not suffice in informing Austria's future citizens what it would mean to be Austrian, though. In addition to Austrian historiographers' deep-seated draw towards a Germanic national narrative, there were also other narrative examples that were used to convey to future citizens the values of Austria. Like the Prussian narratives, the Austrian Emperor, Franz Josef I, was held up as a type of role model (though not to the same extent as Wilhelm I had been), especially in his patronage of the arts and sciences; and it was towards the arts and sciences in particular that whole sections of Austrian textbook historiography were devoted. In addition to learning about the emperor, from the mid- to late-1880s up through the First World War, Austrian historiography shifted gears away from a panGerman (yet anti-Prussian) narrative, both concerning history and the Prussian Wars as well as achievements of German academics and philosophers. Austrian narratives noted not just Austrian accomplishments in commerce, industry, and its new education schemes (i.e. 1869's Reichsvolksschulgesetz), but also highlighted cultural achievements like the great architectural works from turn-of-the-century Vienna: the Parliament building, City hall, University of Vienna main building.

As evidenced, there were different tactics and purposes behind the Austrian historiographic trajectory, those being primarily to honor their historic German nation, 
while also focusing on Germans, and then specifically Austrians, who contributed to the nation. Austrian historiography focused on progress and the arts and sciences in the Fatherland above all else. The evolution of the Austrian narratives over the decades from the 1860s to the 1910s shows that, in its process of nation-building and developing towards becoming a nation-state, Austria gained confidence in itself as a German-Austria (even a Deutschlands Österreich; see Hannak, 1895, pp. 2-3) who valued philosophical and cultural achievements and progression. Austria had become an "us" worthy of respect and deserving of friends; as opposed to the Prussian "other" who had none.

\section{France and a centralized commitment to the Hexagon}

France's history is not any less complicated than those of Denmark or the former Holy Roman Empire (of the German Nation) states. In fact, some parts of France (such as parts of Alsace and Lorraine, the northeastern territories of France that were annexed to Germany in the Franco-Prussian War of 1870-71) had also been counted among this ancient Germanic empire at different points in history. Despite some disputes over borderlands during Medieval and Renaissance times, the 1789 French Revolution, its Declaration of the Rights of Man and of the Citizen (1789) and subsequent constitution in 1791, and eventually the imperial wars spearheaded by Napoléon I (1803-15) left long-lasting effects on the direction of European politics, ideologies, and historiographies. The Napoleonic Wars were themselves quite critical to the development of each of the developing nation-states within this study: during that time, Denmark had been in a type of alliance with France and the Austrian Habsburg-led Holy Roman Empire was dissolved in 1806 (resulting in the opening for greater rivalry between Austria and Prussia as two of the largest member states of the subsequent, loose German Confederation).

After such a close and contentious history with their neighbors to the east, any events that could potentially shift the balance of power away from France even more and towards the center of Europe was heavily anticipated and scrutinized by the French (as well as the rest of the world). Although French narratives did not delve too deeply into the Second Schleswig War of 1864, when they did, it was to mention that Prussia had left it as a small kingdom, but Copenhagen was a very strong place. Just like with the Danish, the Austro-Prussian War of 1866 was not a focal point of the French narratives, and they also did not group Austria together with Germany (or Prussia; in many French narratives, Prussia seemed to be synonymous with Germany, the German Empire, and even the former Holy Roman Empire) nor treat them similarly in their texts. While, according to the narratives, both Germany and Austria were the only great countries in the world who were stingy in trade, Austria was generally praised: they had "distinguishably elegant and tasteful products" and "numerous princely palaces and magnificent literary establishments" for the French (on) to admire (Badré \& Frieh, 1888, pp. 16-17). 
Contrary to the image of Austria, Prussian-Germany had barely been worth mentioning apart from their large centers of industry and science, "powerful empire," and military exploits - but what exploits these were! French historiographers were actually quite descriptive of the vengeful yet successful actions of the Prussian-Germans. After having planned their revenge for the previous fifty years, Prussia took territory from Denmark and vanquished Austria in a "duel" (as French narratives termed it), thereafter triumphantly uniting the other German states with them, becoming the most formidable military power of Europe, crushing the French in the Franco-Prussian War of 1870-71, and forming the German Empire. Since Bismarck was such a great strategist, he had prepared for war accordingly and well in advance; the Germans had had superior troops, who were better armed and better disciplined. Narratives did not represent them as positive role models, though, for they were also described as viciously murdering hostages, pillaging, and destroying France's (nos) most beautiful monuments as they ran over the country, the new Republic.

At the same time that French narratives were relaying the feats of the Germans, they also openly tackled their own missteps and misfortunes leading up to and during the Franco-Prussian War. Unlike the previous national narratives of Denmark and Austria, France's historiographers did not ignore or sugarcoat the French situation that followed, but they did approach it in two distinctly different historiographic tones. According to French narratives published during the first couple decades after the FrancoPrussian War, the results of 1866 had thrown the French into troublesome times, the emperor (Napoléon III) was badly counseled into declaring war on the Prussians, and the French had entered into a war for which they were completely unprepared, thus bringing about his "ruin" and that of France. Following one blow after another, and despite that French patriotism and courage were growing while they were struggling heroically against the Germans, France's Second Empire ended in what the narratives called "a catastrophe that could not have been avoided" (Pointeau \& Lefranc, 1888, p. 312 ) and the French eventually lost the war (and the regions of Alsace and Lorraine). Yet while France wrote about their own detrimental actions, they also used impersonal language to do so (as opposed to the "we" that was regularly used to describe what the French value (on admire...)), thus still separating the unsuccessful events from their future citizens.

The historiographic shift by the twentieth century told a different version of the Franco-Prussian War story, however. Narratives before the First World War described the proceedings of 1870 and 1871 in very clear and vivid language - and it was personal this time (on, notre), with no focus on anyone besides the brutal German troops and the outnumbered, but very admirably courageous French. The acts of war were painted, not from military positions and commanders, but with images of how the furious Germans and the war affected the everyday French: the way bakeries were destroyed, children were killed, and mothers were crying. This was not the end of the narratives, though, because through it all, they were not afraid - everyone was a 
soldier who kept guard - and, in the end, everyone did "like me" and cried for France. Even though the proud and malicious Germans won and took the beautiful regions of Alsace and Lorraine, they still had to suffer because Alsatians and Lorrainians were good Frenchmen who loved, and still love, France. The courageous French soldiers were heroes, "your grandfathers [who] fought bravely to defend our homeland," just like "our soldiers today are also brave" (Lavisse, 1913, pp. 161-162) and France is now well-defended.

In these different French narratives, the negative information was also often followed with something that was positive for the French. For instance, when narratives mentioned France's "shameful capitulation" in Metz in 1871, the future citizens were then quickly reminded of "glorious" French actions against (the Holy Roman Empire's) Charles V (which took place there during the sixteenth century). Not only had the French fortifications and people been "very strong" during these difficult times, but they also immediately tried to forget this disastrous overthrow by working towards prosperity, emphasizing their accomplishments to become the top-ranking European country for industry, commerce, and civilization.

France's own (future) citizens (an "us" that commonly wrote of itself as "we") were constantly reminded of the ancient history, culture, and successes of France. Their narratives often complimented places as "very strong" and told the French future citizens that they admire the different regions of the Hexagon (always including, still, the "lost" ancient regions of Alsace and Lorraine through text and/or maps) for their different qualities, but especially for what they provided in terms of beauty; the arts and architectural and literary feats; education and cultural centers; science, industry, produce and trade; and fortitude. In a similar vein to Bruno's famous French reading book, The Tour of France by Two Children (1877), French historiography aimed at teaching future French citizens to embrace France, good and bad. The Hexagon was a space to feel united by a love of fraternity and of patrie (homeland); where they were to work on loving God and their obligations in a beautiful, virtuous, fidel, and brave manner - but above all, to love "France!" and to be "French," no matter the cost (pp. 6-8). "Vive la France!"

\section{Conclusion}

What we can see is that each of the developing nation-states here had a part to play in at least one if not more of the Prussian Wars, and each has taken advantage of opportunities afterwards to write their own side(s) of the story. Prussia, Denmark, Austria, and France purposed these historiographies for their national curricula, and the resulting narratives were imbued with the nation-specific discourses necessary for creating a specific kind of future citizen. These citizens would have an understanding of history, themselves (as a national "us"), and others (also as "other"; in this case, their neighbors) that would fit the ideals and goals of their nation. 
While Prussian national historiographies were the only ones that consistently covered each of the three Prussian Wars of German Unification in its narratives (for obvious reasons of their high involvement and nation-building purposes), what was included in the narratives of Denmark, Austria, and France also makes clear the differing, and sometimes similar, national goals of each of these developing nation-states. For one, each developing nation-state produced a narrative of what the national "us" identity should look like, strive for, and value. For instance, each was proud of its people for courageously fighting for and bravely defending their country and countrymen. Yet, at the same time, the values that were implied for future citizens were different for each: Prussia favored diligence and peacefulness; Denmark similarly promoted strength and steadfastness; Austria looked to industry, arts, and sciences; as did France with their admiration for beautiful art, literature, and commerce. The aspect of national identities is not all that can be found through historiographic narrative analysis, however. The narratives also shed light on what was important to each from a national perspective: France valued history and culture; Austria, its German nationhood; Denmark turned to its ancient heritage and Scandinavian roots; and Prussia depended on its leader, language, and the historic Fatherland.

Since this case has analyzed the history and geography textbook narratives of developing nation-states which were each involved in the same large case of nationbuilding, we have been able to flesh out how each of the parties involved saw and molded the events to embed and inculcate their own national goals, and from there making some comparisons of the different national goals and historiographic narrative trajectories became possible. It has been made clear that indeed this "same" event is not actually the same. In general, this type of multinational, even decades-spanning, case comparison has afforded a better understanding of how to approach international events (current or otherwise) and nation-building processes. To expand on these purposes, various national "truths," ideals, goals, and identities, can be determined through the reconstruction of the national historiographic paths of different nations, states, and/or nation-states.

\section{References}

\section{Primary (only those referenced in-text)}

Allen, C. F. (1864). Danmarks Historie til Skolebrug. Tiende Udgave. Reitzel.

Badré, A., \& Frieh, T. (1888). La géographie à lécole primaire (leçons, cartes, gravures et devoirs), à lusage des élèves des trois cours. Nouvelle librairie classique, scientifique et littéraire.

Bang, G., \& Ellinger, N. (1892). Larebog i Danmarks Historie. Anbefalet af Ministeriet for Kirke- og Undervisningsveesenet. Wilhelm Prior. 
Hannak, E. (1895). Lehrbuch der Geschichte der Neuzeit für die unteren Classen der Mittelschulen von Dr. Emanuel Hannak. Achte, vollständig umgearbeitete Auflage. Mit Erlass des hohen $k . k$. Ministeriums für Cultus und Unterricht vom 3. Jänner 1895, Z. 29110, zum Unterrichtsgebrauche an Mittelschulen mit deutscher Unterrichtssprache allgemein zugelassen. Hölder.

Hopstein, P. (1871). Preußische Geschichte für Elementarschulen. Bachem.

Jaenicke, H., \& Stohrer, F. (1891). Bilder aus der deutschen und brandenburgisch-preußischen Geschichte. Für Volksschulen bearbeitet. Erster Teil (für die Mittelstufe): Die drei deutschen Kaiser, der Große Kurfürst und die preußischen Könige. Weidmann.

Johannsen, C. (1870). Loerebog i Danmarks Historie for Real- og Borgerskoler, højere Folkeskoler og Almueskoler. Wøldike.

Lavisse, E. (1913). Histoire de France. Cours Élémentaire. Librairie Armand Colin.

Meyer, A. G. (1892). Geschichts-Tabellen: Zahlen und Übersichten für Real- und Höhere Bürgerschulen. Mit besonderer Berücksichtigung der deutschen und der brandenburgischpreussischen Geschichte. Zweiter Teil. Für die obere Stufe. Gaertner.

Pointeau, A., \& Lefranc, A. (1888). Leçons d'Histoire de France. De 1328 à nos jours. Précédées d'une revision des origines à 1328. À l'Usage des Établissements d'Instruction et de Toutes les Écoles Primaires. Cours Moyen, Rédigé en Vue Certificat d'Études Primaires et Conforme au Programme Officiel. Nouvelle Librairie Classique, Scientifique et Littéraire.

Ramsing, A. U. (1906). Mindre Loerebog i Historie. II. Den Nyere Tid. Trykt som Manuskript. Aug. Andersen.

Roßbach, F. (1911). Lehrbuch für den Geschichtsunterricht in mittleren Schulen. I. Teil. Dürr.

Rusch, G., Herdegen, A., \& Tiechl, F. (1909). Lehrbuch der Geschichte. Ausgabe in drei Teilen. Mit Benützung bewährter Erzähler für österreichische Bürgerschulen. III. Teil. Zweite, nach dem neuen Lehrplane bearbeitete Auflage. Pichlers Witwe \& Sohn.

Würfl, C. (1910). Gindelys Lehrbuch der Geschichte für die Unteren Klassen der Mittelschulen. Dritter Teil: Die Neuzeit. Dreizehnte, Umgearbeitete Auflage. Mit Ministerialerlass vom 11. Mai 1910, Z. 18442, allgemein zulässig erklärt. Tempsky.

\section{Secondary}

Berger, S. (1997). The Search for Normality. National Identity and Historical Consciousness in Germany Since 1800. Berghahn Books.

Berger, S. (2007). The Power of National Pasts: Writing National History in Nineteenth- and Twentieth-Century Europe. In S. Berger (Ed.), Writing the Nation: A Global Perspective (pp. 30-62). Palgrave Macmillan. https://doi.org/10.1057/9780230223059 2

Billig, M. (1995). Banal Nationalism. SAGE Publications Ltd.

Boli, J., \& Thomas, G. M. (1997). World Culture in the World Polity: A Century of International Non-Governmental Organization. American Sociological Review, 62(2), 171-190. https:// doi.org/10.2307/2657298

Bruno, G. (1877). Le Tour de la France par Deux Enfants. Devoir et patrie. Belin. http://www. demassieux.fr/TDFWeb/pdf/TDFWeb1877_web.pdf

Buchardt, M. (2020). Educational Biblical Nationalism and the Project of the Modern Secular State. Croatian Journal of Education, 22(2) (this (special) issue). 
Calhoun, C. (2007). Nations Matter: Culture, History, and the Cosmopolitan Dream. Routledge. https://doi.org/10.4324/9780203960899

Cummings, W. K. (1999). The Institutions of Education: Compare, Compare, Compare! Comparative Education Review, 43(4), 413-437. https://doi.org/10.1086/447578

Dahn, N., \& Boser, L. (2015). Learning to See the Nation-State. History, Geography and Public Schooling in Late 19th-Century Switzerland. Bildungsgeschichte. International Journal for the Historiography of Education, 5(1), 41-55.

Fairclough, N. (2003). Analysing Discourse. Textual Analysis for Social Research. Routledge. https://doi.org/10.4324/9780203697078

Foucault, M. (1980). Power and Knowledge. Vintage.

Friedrich, D. S. (2014). Democratic Education as a Curricular Problem: Historical Consciousness and the Moralizing Limits of the Present. Routledge. https://doi.org/10.4324/9781315856896

Kohn, H. (1946). The Idea of Nationalism: A Study in Its Origins and Background. The Macmillan Company. (Original work published 1944)

Kolár. P. (2010). Rewriting National History in Post-War Central Europe: Marxist Syntheses of Austrian and Czechoslovak History as New National Master Narratives. In S. Berger \& C. Lorenz (Eds.), Nationalizing the Past: Historians as Nation Builders in Modern Europe. Writing the Nation Series (pp. 319-340). Palgrave Macmillan. https://doi. org/10.1057/9780230292505 16

Landwehr, A. (2018). Historische Diskursanalyse (2nd ed.). Campus.

Meyer, J. W. (1992). Introduction. In J. W. Meyer, D. H. Kamens, \& A. Benavot (Eds.), School Knowledge for the Masses: World Models and National Primary Curricular Categories in the Twentieth Century (pp. 1-16). Falmer Press.

Meyer, J. W., Boli, J., Thomas, G. M., \& Ramirez, F. O. (1997). World Society and the NationState. American Journal of Sociology, 103(1), 144-181. https://doi.org/10.1086/231174

Montesano Montessori, N. (2014). The potential of narrative strategies in the discursive construction of hegemonic positions and social change. In B. Kaal, I. Maks, \& A. van Elfrinkhof (Eds.), From Text to Political Positions. Text analysis across disciplines (pp. 171187). John Benjamins Publishing Company. https://doi.org/10.1075/dapsac.55.08mon

Osterwalder, F. (2011). Education Programmes, Education Reforms, and the Longue Durée in Historiography of Education. In D. Tröhler \& R. Barbu (Eds.), Education Systems in Historical, Cultural, and Sociological Perspectives. The Future of Education Research (pp. 7-20). Sense Publishers. https://doi.org/10.1007/978-94-6091-827-8 2

Özkırımlı, U. (2017). Theories of Nationalism: A Critical Introduction (3rd ed.). Palgrave Macmillan.

Rogers, R. (2011). Critical Approaches to Discourse Analysis in Educational Research. In R. Rogers (Ed.), An Introduction to Critical Discourse Analysis in Education (2nd ed.) (pp. 1-20). Routledge.

Rüsen, J. (1996). Some Theoretical Approaches to Intercultural Comparative Historiography. History and Theory, 35(4), 5-22. https://doi.org/10.2307/2505441

Samuelsson, J., \& Wendell, J. (2016). A national hero or a Wily Politician? Students' ideas about the origins of the nation in Sweden. Education, 3-13: International Journal of Primary, Elementary and Early Years Education, 1-13. https://doi.org/10.1080/03004279.2015.1130077 
Tröhler, D. (2016a). Curriculum History in Europe: A Historiographic Added Value. Nordic Journal of Educational History, 3(1), 3-24. https://doi.org/10.36368/njedh.v3i1.65

Tröhler, D. (2016b). Curriculum History or the Educational Construction of Europe in the Long Nineteenth Century. European Education Research Journal, 15(3), 279-297. https:// doi.org/10.1177/1474904116645111

Tröhler, D. (2020). National Literacies, or Modern Education and the Art of Fabricating National Minds. Journal of Curriculum Studies, 1-17. https://doi.org/10.1080/00220272 .2020 .1786727

Tröhler, D., Popkewitz, T. S., \& Labaree, D. (Eds.). (2011). Schooling and the Making of Citizens in the Long Nineteenth Century. Routledge. https://doi.org/10.4324/9780203818053

\section{Nicole Gotling}

Department of Education

University of Vienna

Sensengasse 3a, 1090 Vienna, Austria

nicole.gotling@univie.ac.at 


\section{Priče državnih udžbenika i historiografija: predstavljanje istoga koje nikada nije isto}

\section{Sažetak}

Priče državnih udžbenika pisane su iz posebnih nacionalnih perspektiva i ciljeva. Stoga, „isto nije gotovo nikada (ili, u najmanju ruku, nije uvijek) isto”; ono što naučimo ovisi o kontekstu ili o tome kada i gdje učimo. Kada govorimo o velikim sukobima između nacija ili država, odnos prema izvještavanju istoga sukoba može biti posebno pronicljiv. Krenuvši od pisanja o nacionalnim događajima, u ovom tekstu osvrće se na još jedan veliki (inter)nacionalni sukob, pruske ratove (1864.1971.), kako bi se raspravio način na koji su četiri različite nacionalne države u razvoju, Njemačke (kao Prusija), Danska, Austrija i Francuska, elaborirale jedinstvene povijesne narative (od 1860-ih do 1910-ih) za svoje nacionalne kurikule i buduće građane. Iz rezultata koji propituju načine na koje su ove nacionalne države u nastanku predstavile vlastite nacionalne ideale, identitet $i$ ciljeve u svojim državnim pričama o Pruskom ratu u udžbenicima, vraćamo se u sadašnjost s boljim poznavanjem načina na koji pristupiti trenutačnim međunarodnim događanjima i procesima izgradnje nacija.

Ključne riječi: historiografija; izgradnja nacije; nacionalni identitet; nacionalne priče; pruski ratovi; udžbenici. 